\title{
Biochemical, physical and sensory quality of ice-stored Atlantic cod (Gadus morhua) as affected by pre-slaughter stress, percussion stunning and AQUI-S ${ }^{\mathrm{TM}}$ anaesthesia
}

\author{
Hanne Digre • Ulf Erikson • Josefine Skaret • \\ Per Lea · Lorena Gallart-Jornet · Ekrem Misimi
}

Received: 8 February 2011/Revised: 3 June 2011/Accepted: 26 June 2011/Published online: 12 July 2011

(C) The Author(s) 2011. This article is published with open access at Springerlink.com

\begin{abstract}
Biochemical, physical and sensory quality of farmed Atlantic cod subjected to percussion stunning (control), anaesthesia (AQUI-S ${ }^{\mathrm{TM}}$ ) and excessive exercise (30 min chasing before slaughter, 'stressed') were analysed after 7 days of ice storage. The white muscle energy status (initial $\mathrm{pH}$, muscle twitches and high-energy phosphates) revealed that the fish were truly representatives of rested (percussion stunned and anaesthetised) and stressed cod. Sensory evaluation showed that the fillets of cod exposed to percussion stunning and AQUI-S $S^{\mathrm{TM}}$ anaesthesia prior slaughter had slightly higher whiteness scores, and that the fillets of AQUI-S $S^{\text {TM }}$ anaesthetised cod had slightly shinier surfaces than the fillets of cod exposed to pre-slaughter stress. Furthermore, fillets of anaesthetised (AQUI-S ${ }^{\mathrm{TM}}$ ) cod had significantly higher inosine monophosphate (IMP) contents and lower K-values than fillets of cod exposed to pre-slaughter stress, after 7 days of ice storage. Preslaughter stress did to some extent affect fillet colour immediately after killing and after ice storage. Otherwise, no significant effects of stress were observed with regard to biochemical, physical or sensory quality (ultimate $\mathrm{pH}$, water content, drip loss, water holding capacity, texture and gaping) of farmed Atlantic cod.
\end{abstract}

H. Digre $(\varangle) \cdot$ U. Erikson · L. Gallart-Jornet · E. Misimi SINTEF Fisheries and Aquaculture, 7465 Trondheim, Norway e-mail: Hanne.Digre@fhf.no; hanned2@online.no

H. Digre

Department of Biotechnology, The Norwegian University

of Science and Technology, 7491 Trondheim, Norway

J. Skaret · P. Lea

NOFIMA Mat AS, 1430 Ås, Norway
Keywords Sensory analysis - Biochemical quality · Atlantic cod $\cdot$ Handling stress $\cdot$ AQUI-S ${ }^{\mathrm{TM}}$.

Pre-slaughter stress

\section{Introduction}

Atlantic cod (Gadus morhua) is being developed for aquaculture in Norway. In 2009, approximately 20,000 metric tonnes (round weight) were produced. This represents about $48 \%$ increase from 2008 [1]. As fish welfare is of major concern for the aquaculture industry and consumers, it must be addressed in farming and harvesting [2]. Robb and Kestin [3] described the concerns of fish welfare and flesh quality related to different slaughter methods used commercially worldwide. They concluded that methods that cause a rapid loss of sensibility result in the best welfare and produce the highest quality product. Reduced stress prior to slaughter has been shown to have a positive influence on flesh quality, e.g. gaping and colour, for farmed Atlantic cod [4, 5]. Misimi et al. [6] reported for farmed Atlantic cod that greater activity immediately prior to death results in a more rapid drop in muscle $\mathrm{pH}$ and a shorter period to the onset of rigor. Sveinsdóttir et al. [7] evaluated sensory characteristics of unstressed and stressed farmed cod by using a trained sensory panel and consumer evaluation tests. They found that the texture attributes differed with regard to stress levels prior to slaughter. The panel found that the low-stress fish had more meaty and rubbery texture, whereas the stressed fish were more tender. However, the consumer test scored the stressed fish higher with regard to overall liking. Stress prior to slaughter of farmed Atlantic salmon caused a lower sensory score for the parameters texture and odour after 9 and 10 days of storage at $3.3{ }^{\circ} \mathrm{C}$ [8]. 
Different fish slaughter methods have been described. Percussion stunning is considered as a method that does cause immediately loss of consciousness, and when it is applied correctly, it is one of the best methods in terms of fish stress and flesh quality [3]. However, methods as AQUI-S ${ }^{\mathrm{TM}}$, described as a method that does not cause immediately loss of consciousness, could be applied. AQUI-S ${ }^{\mathrm{TM}}$, a food-grade fish anaesthetic with iso-eugenol as the active ingredient, has been associated with reduced muscle activity prior to killing which in turn results in good flesh quality $[9,10]$. However, there are concerns that fish anaesthetised with AQUI-S ${ }^{\mathrm{TM}}$ could be tainted with a clove oil flavour [3]. It is not clear whether AQUI-S ${ }^{\mathrm{TM}}$ have true anaesthetic properties and induces insensibility, or whether it is merely sedative in action, but fish sedated prior to slaughter appear to suffer far less distress than untreated fish [3, 11]. Nevertheless, the anaesthetic seems to render Atlantic salmon in a state of unconsciousness since no fish exhibited VOR (vestibulo-ocular reflex) after stunning or after $10 \mathrm{~min}$ of recovery in fresh seawater [12]. If percussion stunning is applied correctly, it is identified as one of the best methods in terms of fish welfare, stress and flesh quality [3].

Kildea et al. [13] studied the accumulation and clearance of clove oil and AQUI-S ${ }^{\mathrm{TM}}$ from the edible tissue of silver perch, and found that the residue was cleared to below detectable levels in all fish after $48 \mathrm{~h}$, independently of the dosage of the anaesthetic $\left(15\right.$ and $50 \mathrm{mg} \mathrm{L}^{-1}$ clove oil or AQUI- $S^{\mathrm{TM}}$ ). Meinertz et al. [14] reported that the isoeugenol concentrations in rainbow trout fillet tissues were influenced by exposure time and concentration of the AQUI-S ${ }^{\mathrm{TM}}$, as well as water temperature. Fletcher et al. [15] investigated the effect of using $\mathrm{CO}_{2}$ stunning and AQUI-S ${ }^{\text {TM }}\left(20 \mathrm{mg} \mathrm{L}^{-1}\right)$ on the spoilage of king salmon stored in air packs for 5-22 days. They found minimal differences between the treatments on the sensory evaluation, included appearance, odour, texture and overall quality index score.

AQUI-S $S^{\text {TM }}$ anaesthesia of Atlantic cod and the impact of sensory quality have to our knowledge not yet been reported in the literature. Biochemical, physical and sensory quality of Atlantic cod as affected by pre-slaughter stress, percussion stunning or AQUI-S ${ }^{\mathrm{TM}}$ anaesthesia were studied. The main objective was to elucidate whether pre-slaughter handling stress caused inferior post-rigor fillet quality.

\section{Materials and methods}

Fish sampling

Farmed Atlantic cod (weight: $3.0 \pm 0.4 \mathrm{~kg}$; fork length: $61 \pm 4 \mathrm{~cm}, n=37$ ) were obtained from a fish farm located at Roan in Central Norway in August 2007. The mean condition factor $(\mathrm{CF})$ and hepatosomatic index (HSI) were $1.3 \pm 0.2$ and $8.6 \% \pm 1.7 \quad($ mean $\pm \mathrm{SD}, \quad n=37$ ) respectively.

The fish were netted from the sea cage and transferred to two tubs containing clean seawater (SW, salinity $35 \mathrm{ppt}$ ). A small boat transported the tubs for $5 \mathrm{~min}$ and the tubs were brought ashore. The fish were immediately netted into two transport tanks on a truck used for commercial transport of live fish. The tanks contained clean SW and they were oxygenated during the transport (about $3 \mathrm{~h}$ ) to our laboratory. The fish densities in both tanks were approximately $56 \mathrm{~kg} \mathrm{~m}^{-3}$. At arrival, the dissolved oxygen concentration (DO), water temperature and $\mathrm{pH}$ in the $\mathrm{SW}$-filled tanks were $94-112 \%$ saturation, $13.8{ }^{\circ} \mathrm{C}$ and 6.3 , respectively. No mortalities occurred during the transport, but 5-10 fish were in a rather poor condition. The fish were then transferred in SW-filled 1,000 L tubs to two holding tanks (4,000 L, 75\% filling). Six fish died after $5 \mathrm{~h}$ being transferred to the tanks. The fish, equally distributed among the tanks, were kept for 3 days without feeding at a fish density of approximately $19 \mathrm{~kg} \mathrm{~m}^{-3}$. SW from $80 \mathrm{~m}$ depth was pumped, sand-filtered and circulated to the tanks at a rate of $5 \mathrm{~m}^{3} \mathrm{~h}^{-1}$. During the holding period, the water temperature and DO in both tanks were within the ranges of $11.5-11.6{ }^{\circ} \mathrm{C}$ and $89-100 \%$ saturation, respectively. The fish were calm and exhibited a normal swimming behaviour during this 3 day period.

Control (percussion stunned) group: At the start of the experiment, twelve fish were randomly collected from one of the holding tanks, gently brailed one by one from the tank and stunned by a sharp blow to the head (percussion stunned).

AQUI-S ${ }^{\mathrm{TM}}$ (anaesthetised) group: One day before the start of the experiment, 12 fish, one at the time, were gently dipnetted from the holding tank into two smaller SW-filled tanks ( $400 \mathrm{~L}$, six fish in each tank, $75 \%$ filling) at a fish density of approximately $60 \mathrm{~kg} \mathrm{~m}^{-3}$. The DO level and water temperature in these tanks were within the ranges of 75-77\% saturation and $11.8-11.9^{\circ} \mathrm{C}$, respectively. On the next morning, the water supply to the tanks was stopped and a pre-defined amount of AQUI-S ${ }^{\text {TM }}$ (AQUI-S Ltd, Lower Hutt, NZ) was added to give a final concentration of $17 \mathrm{mg} \mathrm{L}^{-1}$. During exposure to the anaesthetic, oxygen gas was added to the tanks through a diffuser (Point Four Systems Inc., Ricmond, Canada). After 20 min, all fish were judged as fully anaesthetised since most fish were lying on the bottom of the tank (stage 4; total or complete loss of equilibrium, [16]). No vigorous muscle activity took place during the treatment. Behavioural observations were assessed to define the progression of anaesthesia in the fish [16]. The fish were lifted individually from the tank between 20 and 54 min after the anaesthetic was added to 
the tank and killed by a sharp blow to the head. The same procedure was repeated with the fish from the second tank where the fish were killed 16-53 min after the anaesthetic was added to the tank.

Stressed group: The remaining fish in the holding tank were stressed by chasing for $30 \mathrm{~min}$. At the same time, the water level in the tank was reduced to a height of about $10 \mathrm{~cm}$. The fish, not allowed to recover, were killed by a blow to the head within 30 min after the stress bout.

Ethics: The experiments were conducted in accordance with the Norwegian Animal Welfare Act and the experimental design was approved by SINTEF Fisheries and Aquaculture personnel authorised by the Norwegian National Animal Research Authority.

All fish were treated in the same way afterwards. All gill arches on one side of the head were severed. Then, the fish were immediately held head down over a bowl and blood drained off for $2 \mathrm{~min}$ was collected and weighed. The initial $\mathrm{pH}$ was then measured directly in the white muscle between the first dorsal fin and the lateral line after a cut had been made by a scalpel. In the same area, a 1-2 g muscle sample (without skin) was excised and freeze-clamped using aluminium tongs immersed in liquid nitrogen. The frozen samples were stored in liquid nitrogen before they were transferred to a $-80{ }^{\circ} \mathrm{C}$ freezer where they were stored until analysis of high-energy phosphates (HEP) and related products. The white muscle twitch response was then measured before fork length, body and liver weights were determined. Subsequently, the fish were gutted, filleted and briefly washed under cold running tap water. The left fillets were then subjected to colour analysis, white epaxial muscle samples $(2 \mathrm{~g})$ were excised for determination of total water content and the fillet weighted. Furthermore, the fillets were packed individually in plastic bags, tagged and stored on ice in Styrofoam boxes in a cold room $\left(<4{ }^{\circ} \mathrm{C}\right)$ for 7 days. The right fillets were used for sensory evaluation. These fillets were packed in the same way as the left fillets, but after 1 day of storage the fillets were sent to NOFIMA Mat AS, Ås, Norway. After 7 days of ice storage, fillet weight, ATP-degradation products, K-value, ultimate $\mathrm{pH}$, water content, water holding capacity, colour, texture and visual assessment of gaping were determined on the left fillets. The sensory assessment was partly carried out on the same day as well as on the day before.

White muscle $\mathrm{pH}$, muscle twitches, high-energy phosphates and $\mathrm{K}$-values

A shielded glass electrode (WTW SenTix 41) connected to a portable pH meter (model WTW 315i; WTW, Weilheim, Germany) was used to measure white muscle
pH. A Twitch Tester Quality Assessment Tool (AQUI-S Ltd.) was used to measure the muscle twitches. An electrical pulse was generated ( $9 \mathrm{~V} \mathrm{DC}$ ) by the instrument every $0.6 \mathrm{~s}$. One, or a few $(<3)$, measurements were performed on one side of each fish immediately after slaughter. The electrodes were placed along the entire lateral line, and were in contact with the fish for about $1 \mathrm{~s}$. The following scale was devised: 3 : Strong twitch; whole body twitch; 2: Weaker twitch; tail or head region twitch; 1: Muscle contractions in (small) restricted areas on the fish surface; 0: No twitch.

White epaxial muscle samples were excised and freezeclamped immediately after sampling as described by Erikson et al. [17]. After freeze-drying (Hetosicc, mod. CD 13-1, Heto Lab Equipment A/S, Birkerød, Denmark), the samples were analysed using the method of Sellevold et al. [18], as modified by Erikson et al. [17]. The HPLC used was a model from Waters Alliance 2695, Detector 2487 dual wavelength UV/VIS (Massachusetts, USA) and a Supelco Discovery HS C18 $(15 \mathrm{~cm} \times 4.6 \mathrm{~mm}, 3 \mu \mathrm{m})$ column (Pennsylvania, USA), operating at the following conditions: flow rate $1.0 \mathrm{~mL} \mathrm{~min}{ }^{-1}$ at $4{ }^{\circ} \mathrm{C}$; UV monitoring at $254 \mathrm{~nm}$ for adenosine triphosphate (ATP) and related degradation products and at $206 \mathrm{~nm}$ for phosphocreatine ( $\mathrm{PCr}$ ); the micro-filtered isocratic mobile phase, adjusted to $\mathrm{pH} 6.25$ consisted of $\mathrm{KH}_{2} \mathrm{PO}_{4}(215 \mathrm{mM})$, tetrabutylammonium hydrogen sulphate (TBAHS, $0.08 \%$ ) and acetonitrile (3.5\%). K-values were calculated as:

$$
\begin{aligned}
\mathrm{K}= & {[(\mathrm{HxR}+\mathrm{Hx}) /(\mathrm{ATP}+\mathrm{ADP}+\mathrm{AMP}+\mathrm{IMP}+\mathrm{HxR}+\mathrm{Hx})] } \\
& \times 100 \%,
\end{aligned}
$$

where HxR is inosine, Hx is hypoxanthine, ADP is adenosine diphosphate, AMP is adenosine monophosphate and IMP is inosine monophosphate. All metabolites were calculated as $\mu$ mol g ${ }^{-1}$ muscle (dry wt).

Fillet water content, water holding capacity and drip loss

The water content of the epaxial muscle was determined by drying duplicates of approximately $2 \mathrm{~g}$ sample at $105{ }^{\circ} \mathrm{C}$ for $24 \mathrm{~h}$. The difference in weight before and after drying was taken as the total water content of the sample. Water holding capacity (WHC) was determined on approximately $2 \mathrm{~g}$ minced white muscle sample, by low-speed centrifugation as described by the method of Eide et al. [19], but with a centrifugation force of $210 \mathrm{~g}$. The analyses were run in quadruplicate. The WHC is expressed as the percentage of water retained in the mince after centrifugation for 5 min. Fillet per cent drip loss during storage was calculated as $100 \%$ * (initial fillet weight - final fillet weight)/ initial fillet weight. 
Fillet texture and gaping

The measurements were performed on chilled fillets immediately after being taken from the Styrofoam boxes. Fillet hardness was measured by using a TA.XT2 Texture Analyser (Stable Micro Systems, Surrey, England) equipped with a load cell of $5 \mathrm{~kg}$. A flat-ended cylindrical plunger (12 $\mathrm{mm}$ diameter) was pressed into the fillets perpendicular to the muscle fibres at a constant speed of $5 \mathrm{~mm} \mathrm{~s}^{-1}$ until it reached $60 \%$ of the sample height. The measurement was repeated at three different locations along the dorsal muscle (anterior, middle and posterior parts). The gaping frequency was subsequently assessed subjectively by using scores ranging from 0 to 5 according to the number of slits in the fillets with skin on after a method described by Andersen et al. [20].

\section{Fillet colour}

The colour analysis of fillets was assessed objectively by using the computer vision method reported by Erikson and Misimi [21]. Colour analysis was done in the CIE $L^{*} a^{*} b^{*}$ colour space. The fillet images were colour calibrated using the Macbeth ColourChecker and the $L^{*} a^{*} b^{*}$ values were obtained by calculating the mean values over the pixels of the fillet area excluding the peritoneal lining in the belly region (see Fig. 1). In addition, the hue angle $\mathrm{H}_{\mathrm{ab}}^{\circ}$ $\left(0^{\circ}=\right.$ red hue; $60^{\circ}=$ yellow hue) and chroma $\mathrm{C}_{\mathrm{ab}}$ (colour saturation; higher values mean more intense colour perception) were calculated as $\mathrm{H}_{\mathrm{ab}}^{\circ}=\arctan \left(\mathrm{b}^{*} / \mathrm{a}^{*}\right)$ for $\mathrm{a}^{*}>0$, and as $\mathrm{C}_{\mathrm{ab}}=\left(\mathrm{a}^{*^{2}}+\mathrm{b}^{* 2}\right)^{1 / 2}$, respectively. Whiteness was calculated as $L^{*}-3 b^{*}[22]$.

The computer vision method is reported to give generally higher values, except for hue values, than obtained with the Minolta Chroma Meter, as seen in Atlantic salmon [21]. The Minolta Chroma Meter is perhaps a more traditional method used to evaluate the fillet colour, and is therefore difficult to compare values obtained from these two methods. The general differences in CIE $L^{*} a^{*} b^{*}$ values between the two methods might be due to the fact that the Minolta method obtain the values in direct contact with the flesh, whereas with the computer vision method, the entire fillet area is subjected to colour analysis.

\section{Sensory evaluation}

The trained panel consisted of nine persons employed exclusively to work as sensory assessors at NOFIMA Mat AS. The assessors have a minimum of 3 years of experience in sensory evaluation using descriptive analysis in a variety of foods and beverages. The panellists have been selected and trained according to recommendations in ISO [23], and a descriptive method as recommended in ISO
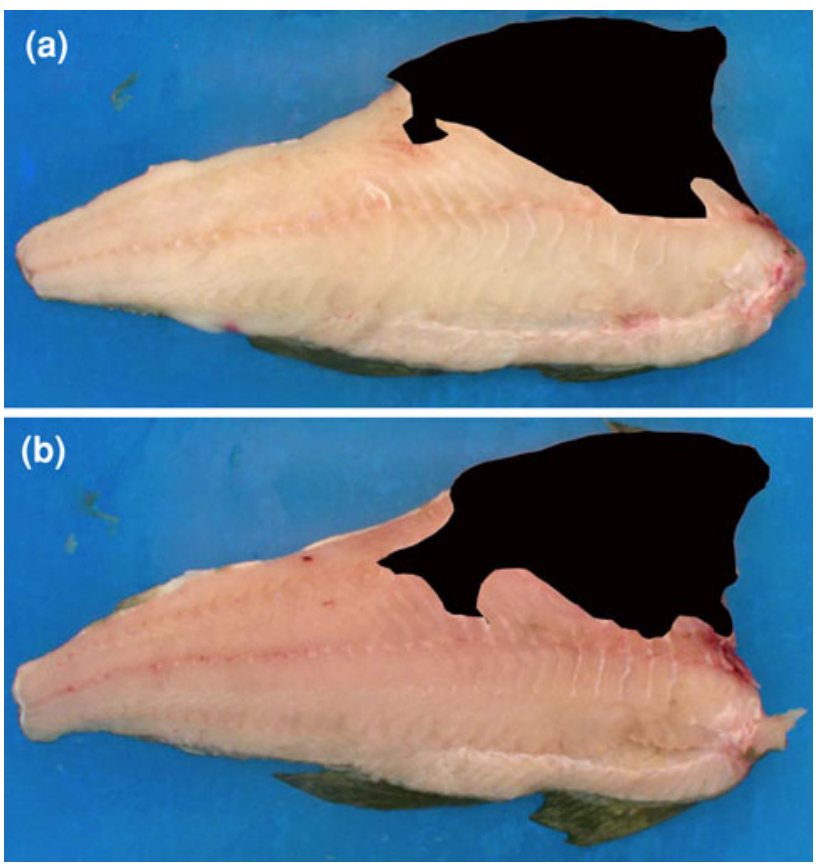

Fig. 1 Captured images of fillets without the peritoneal lining in the belly region, showing the fillet colour of; a 'white' fillet and b 'pinkish' fillet

[24] was used for the evaluation. The sensory laboratory was designed according to guidelines in ISO [25] with separate booths and electronic registration of data (CSA, Compusense Five, Version 4.6, Guelph, Ontario, Canada, 1999).

Each assessor was served samples from the same anatomical region of the fish for each fillet to avoid possible variation between samples due to natural differences in the fish anatomy, so assessor number one was always served a slice from the front part of the fillets and assessor number nine always from the tail part. Fillets were cut in $15-\mathrm{mm}$ thick serving pieces and packed in plastic bags marked with three digit codes and vacuumed before being cooked for $10 \mathrm{~min}$ in a pre-warmed oven (Electrolux, AOS061Eelectric steam/convection oven, Sweden) at $85{ }^{\circ} \mathrm{C}$ with air circulation and steam. The samples were evaluated at approximately $60{ }^{\circ} \mathrm{C}$.

Prior to the trial, the panel was trained and calibrated on cooked cod of expected different sensory qualities. The assessors developed a list of attributes and agreed on a consensus list for the profiling and on the definition of each attribute. The panel was not informed that some of the fish had been exposed to AQUI- ${ }^{\mathrm{TM}}$. The heated samples were evaluated for 13 sensory attributes (Table 1).

The samples were served in coded plastic bags and each assessor individually opened the bag immediately for registration of sample odour. Each panellist evaluated 30 samples in 2 days during six sessions. Samples were assessed in random order according to group, replicate (10 
Table 1 Sensory attributes for cooked cod fillets evaluated by the trained sensory panel

\begin{tabular}{ll}
\hline Attribute & Definition \\
\hline A-gloss & Shiny surface \\
A-coarseness & $\begin{array}{l}\text { Degree of granularity of the muscle fibres } \\
\text { Paleness, lack of pure colour or black }\end{array}$ \\
A-whiteness & Fruity/fresh and sour/sweet \\
O-sour & Fresh, salty, sea, ocean \\
O-seawater & Fruity/fresh and sour/sweet \\
F-sour & Flavour of bitter substance, like quinine \\
F-bitter & Flavour of salt substance, NaCl \\
F-salt & Ferro sulphate, blood, iron \\
F-metallic & Fresh, salty, sea, ocean \\
F-seawater & Degree of granularity of the muscle fibres \\
T-coarseness & The force required to bite through the sample \\
T-hardness & Moist, perception of water released \\
T-juiciness &
\end{tabular}

$A$ appearance, $O$ odour, $F$ flavour, $T$ texture

fillets) and assessor. Unsalted crackers and lukewarm water were available for rinsing the palate between samples. The panellists recorded their results at individual speed on a $15-\mathrm{cm}$ non-structured continuous scale with the left side of the scale corresponding to the lowest intensity and the right side corresponding to the highest intensity of each attribute. The computer transformed responses into numbers between $1=$ low intensity and $9=$ high intensity.

\section{Statistical analysis}

The sensory data were analysed using ANOVA (Analysis of Variance). The ANOVA model is:

$X_{i j k}=\mu+\alpha_{i}^{M}+b_{j}^{A}+\alpha b_{i j}^{M \times A}+e_{k(i)}^{F(M)}$,

where $\mu$ is a general mean, $\alpha_{i}^{M}$ is method $i,(i=$ control, AQUI-S ${ }^{\mathrm{TM}}$, stress), $b_{j}^{A}$ is assessor $j(j=1,2, \ldots, 9), \alpha b_{i j}^{M \times A}$ is the method $\times$ assessor interaction and $e_{k(i)}^{F(M)}$ is fish $\mathrm{k}$, nested within method $(\mathrm{k}=1,2, \ldots, 10)$. The method effect is fixed, while assessor, method $\times$ assessor interaction and fish within method are all random effects. As a consequence, the Satterthwaite approximation [26] had to be applied to test the method effect. Thus, the error term of the method $F$ test was the following linear combination of mean squares:

\section{MS(Fish(Method) $)+$ MS(Method $\times$ Assessor $)$ - MS(Error),}

with the degrees of freedom being estimated by the Satterthwaite method [26].

The effect of treatment (control, AQUI-S ${ }^{\mathrm{TM}}$, stress) on different parameters was analysed using a one-way ANOVA. Where significance $(p<0.05)$ was indicated, a
Tukey post hoc test was run. The discrete variables data (muscle twitches and gaping) were tested using non-parametric statistics (Kruskall Wallis). The results are reported as means \pm standard error of means (SEM).

\section{Results and discussion}

Post-slaughter classification of fish according to stress level

The anaesthetised and the percussion stunned cod exhibited typical initial muscle $\mathrm{pH}$ values of rested cod at $\mathrm{pH}$ 7.4-7.5 (Table 2). Comparable values ( $\mathrm{pH} 7.2-7.5)$ are reported for unstressed farmed Atlantic cod [4, 6]. Kristoffersen et al. [5] reported a higher $\mathrm{pH}$ value, 7.9, for farmed cod killed with as little pre-slaughter activity as possible. In our stressed fish, the values were typical, $\mathrm{pH} 7.0$, and were in accordance to previously reported $\mathrm{pH}$ values for stressed cod [4-6]. Low pH at the time of killing is widely recognised as an indicator of handling stress. During stress and muscle activity prior to slaughter white muscle is predominantly used and large amounts of lactic acid in the muscle will be produced. Together with $\mathrm{H}^{+}$from ATP degradation, this will result in low initial white muscle $\mathrm{pH}$ [10], as observed in this study. The twitch tester values (Table 2) were different between the groups whereas the corresponding values of stressed fish were significantly lower. The pre-rigor white muscle water content (about $80 \%$ ) was not affected by handling stress (Table 2). The anaesthetised cod had a significantly higher drain-off of blood $(1.7 \%)$ than percussion stunned $(1.0 \%)$ and stressed fish $(1.1 \%$, Table 2$)$. The blood volume for our anaesthetised cod is within the range (1.5-3.0\%) of what is typical for different fish species [27]. It has been shown that perimortem handling stress increases the rate of coagulation [28], which might reduce the effect of bleeding.

The initial values of PCr, ATP and IMP for the different groups are presented in Table 2. Anaesthetised and percussion stunned cod exhibited significantly higher $\mathrm{PCr}$ $\left(111.3 \mu \mathrm{mol} \mathrm{g}^{-1}\right.$, dry wt $)$ and ATP $\left(\sim 26.1 \mu \mathrm{mol} \mathrm{g}^{-1}\right.$, dry wt) contents in white muscle compared with stressed cod (PCr: $22.3 \mu \mathrm{mol} \mathrm{g}{ }^{-1}$, ATP: $18.2 \mu \mathrm{mol} \mathrm{g}^{-1}$, dry wt). In more active species such as Atlantic salmon, the $\mathrm{PCr}$ content in the muscle can be almost completely depleted at the time of death when the fish are stressed to exhaustion [17]. By comparison, Fraser et al. [29] reported similar levels of ATP $\left(25 \mu \mathrm{mol} \mathrm{g}{ }^{-1}\right.$, dry wt, recalculated data assuming a white muscle water content of $80 \%$ ) in rested cod muscle. The IMP levels of our anaesthetised and the percussion stunned cod were significantly lower $\left(\sim 1.2 \mu \mathrm{mol} \mathrm{g}^{-1}\right.$, dry wt) compared with the stressed cod $\left(7.5 \mu \mathrm{mol} \mathrm{g}{ }^{-1}\right.$, dry wt). The AMP and ADP contents on the 
Table 2 White muscle biochemistry, including distribution of phosphocreatine (PCr), adenosine triphosphate (ATP) and inosine monophosphate (IMP), and different quality parameters, including distribution of inosine monophosphate (IMP), inosine (HxR) and hypoxanthine $(\mathrm{Hx})$ in white muscle, of farmed Atlantic cod from different groups: percussion stunned (Control), anaesthetised (AQUI$\mathrm{S}^{\mathrm{TM}}$ ) or stressed by chasing (Stress) determined at the day of slaughter $(0 \mathrm{~h})$ and after 7 days of ice storage

\begin{tabular}{|c|c|c|c|}
\hline Groups & Control & AQUI-S ${ }^{\mathrm{TM}}$ & Stress \\
\hline \multicolumn{4}{|l|}{ Day 0} \\
\hline Initial muscle $\mathrm{pH}$ & $7.4 \pm 0.0^{\mathrm{a}}$ & $7.5 \pm 0.0^{\mathrm{a}}$ & $7.0 \pm 0.1^{\mathrm{b}}$ \\
\hline Twitch tester (range $0-3$ ) & $3.0 \pm 0.0^{\mathrm{a}}$ & $2.9 \pm 0.1^{\mathrm{a}}$ & $2.0 \pm 0.1^{\mathrm{b}}$ \\
\hline $\operatorname{PCr}\left(\mu \mathrm{mol} \mathrm{g}{ }^{-1}\right.$, dry wt $)$ & $111.3 \pm 8.2^{\mathrm{a}}$ & $111.3 \pm 10.1^{\mathrm{a}}$ & $22.3 \pm 6.7^{b}$ \\
\hline ATP $\left(\mu \mathrm{mol} \mathrm{g}{ }^{-1}\right.$, dry wt $)$ & $25.4 \pm 1.4^{\mathrm{a}}$ & $26.8 \pm 1.0^{\mathrm{a}}$ & $18.2 \pm 1.6^{\mathrm{b}}$ \\
\hline IMP $\left(\mu \mathrm{mol} \mathrm{g}{ }^{-1}\right.$, dry wt) & $2.4 \pm 0.8^{\mathrm{a}}$ & $2.0 \pm 0.2^{\mathrm{a}}$ & $7.5 \pm 1.4^{\mathrm{b}}$ \\
\hline Blood weight ( $\%$ of body weight) & $1.0 \pm 0.1^{\mathrm{b}}$ & $1.7 \pm 0.2^{\mathrm{a}}$ & $1.1 \pm 0.9^{\mathrm{b}}$ \\
\hline Pre-rigor water content $(\%)^{\mathrm{NS}}$ & $78.8 \pm 0.2$ & $78.8 \pm 0.1$ & $78.9 \pm 0.2$ \\
\hline \multicolumn{4}{|l|}{ Day 7} \\
\hline K-value $(\%)$ & $59.4 \pm 3.7^{\mathrm{ab}}$ & $52.7 \pm 2.4^{\mathrm{a}}$ & $67.5 \pm 3.6^{\mathrm{b}}$ \\
\hline IMP $\left(\mu \mathrm{mol} \mathrm{g}{ }^{-1}\right.$, dry wt) & $10.0 \pm 1.3^{\mathrm{ab}}$ & $12.2 \pm 1.0^{\mathrm{a}}$ & $7.2 \pm 1.0^{\mathrm{b}}$ \\
\hline $\operatorname{HxR}\left(\mu \mathrm{mol} \mathrm{g}{ }^{-1} \text {, dry wt }\right)^{\mathrm{NS}}$ & $16.4 \pm 1.4$ & $14.1 \pm 0.6$ & $18.0 \pm 1.3$ \\
\hline Hx $\left(\mu \mathrm{mol} \mathrm{g}^{-1} \text {, dry wt }\right)^{\mathrm{NS}}$ & $2.2 \pm 0.2$ & $2.3 \pm 0.2$ & $2.3 \pm 0.2$ \\
\hline Ultimate muscle $\mathrm{pH}^{\mathrm{NS}}$ & $6.3 \pm 0.0$ & $6.4 \pm 0.0$ & $6.4 \pm 0.0$ \\
\hline Water content $(\%)^{\mathrm{NS}}$ & $80.2 \pm 0.4$ & $79.9 \pm 0.2$ & $80.2 \pm 0.2$ \\
\hline $\mathrm{WHC}^{\mathrm{NS}}$ & $80.4 \pm 0.8$ & $82.0 \pm 1.4$ & $82.8 \pm 1.4$ \\
\hline Fillets drip loss $(\%)^{\mathrm{NS}}$ & $0.2 \pm 0.9$ & $2.1 \pm 1.1$ & $3.3 \pm 1.4$ \\
\hline Gaping (range $0-5)^{\mathrm{NS}}$ & $0.5 \pm 0.2$ & $0.9 \pm 0.4$ & $0.7 \pm 0.3$ \\
\hline
\end{tabular}

Different letters (a-b) indicate significant differences between the groups $(p<0.05)$. NS no significant differences between groups $(p>0.05)$. Mean $\pm \operatorname{SEM}(n=6-13)$

day of slaughter were approximately 0.4 and $3.3 \mu \mathrm{mol} \mathrm{g} \mathrm{g}^{-1}$ (dry wt), respectively. In line with the present study, Bosworth et al. [11] reported higher ATP contents in the muscle of channel catfish anaesthetised with AQUI-S ${ }^{\mathrm{TM}}$ (30 $\mathrm{mg} \mathrm{L}^{-1}$ ) compared to stressed fish at the time of killing. Based on the initial muscle $\mathrm{pH}$, muscle twitches, $\mathrm{PCr}$, ATP and IMP values we conclude that the fish subjected to quality analysis were truly representatives of either rested or stressed cod.

\section{Biochemical and physical quality}

The distribution of IMP, HxR and Hx in the fillets after 7 days post-mortem is presented in Table 2. The fillets from the AQUI-S ${ }^{\mathrm{TM}}$ group had significantly higher IMP contents $\left(12 \mu \mathrm{mol} \mathrm{g}{ }^{-1}\right)$ than the fillets from the stressed group $\left(7 \mu \mathrm{mol} \mathrm{g}^{-1}\right)$. The HxR (neutral taste) contents of the fish ranged from 14 to $18 \mu \mathrm{mol} \mathrm{g}^{-1}$ (dry wt), while the mean $\mathrm{Hx}$ (bitter taste) contents were $2 \mu \mathrm{mol} \mathrm{g}^{-1}$ (dry wt) for all the groups. IMP is identified as flavour enhancers in fish meat and the flavour threshold value of IMP occurs at around $5.0 \mu \mathrm{mol} \mathrm{g}^{-1}$ (dry wt, recalculated assuming a white muscle water content of $80 \%$ ) regardless of the fish species [30]. The formation of $\mathrm{HxR}$ and $\mathrm{Hx}$ are indicative of a decrease in freshness closely correlated with loss of flavour. Greene and Bernatt-Byrne [31] showed that IMP and HxR content in Pacific cod and pollock positively correlated with overall desirability, while there was a negative correlation between $\mathrm{Hx}$ and flavour. Critical $\mathrm{Hx}$ values for unacceptable sensory scores for Pacific cod are reported to be $3.0 \mu \mathrm{mol} \mathrm{g}^{-1}$ [31]. The mean $\mathrm{Hx}$ value in our study was below the critical limit Hx values. Digre et al. [32] reported somewhat higher values for electrical stunned cod after 8 days of ice storage, with mean IMP, HxR and Hx contents of approximately 12, 23 and $4 \mu \mathrm{mol} \mathrm{g}{ }^{-1}$, respectively. The $\mathrm{K}$-value has been used as a freshness index of fish products [33]. Our mean K-value after storage for 7 days was significantly lower for the AQUI-S ${ }^{\mathrm{TM}}$ group than for the stressed group (Table 2). Handling stress during harvest has been reported to increase K-values [17]. Erikson et al. [17] suggested an upper K-value limit of $70-80 \%$ for good quality Atlantic salmon, and lower than $40-50 \%$ for excellent quality.

The ultimate $\mathrm{pH}$ values were around 6.4 with no differences between the groups (Table 2). This is in line with the findings of Kristoffersen et al. [5]. The fillet water contents and WHCs were on average 80.1 and $81.7 \%$, respectively, with no differences between the groups (Table 2). Similar values are reported by Hultmann and Rustad [34]. Fillet drip loss, an important quality parameter, was also assessed (Table 2). During storage, the fillets lost weight, ranging from 0.2 to $3.3 \%$, but there were no 
significant differences between groups. There was a tendency that the fish from the control group lost less water (weight) than fish in the other groups, but the difference was not significant $(p=0.18)$. By comparison, Bosworth et al. [11] found that fillet drip loss was lower for rested fish than for fish subjected to simulated transport (stressed).

The mean gaping score after 7 days of storage was 0.7 with no difference between the groups (Table 2). No significant differences were observed between our groups with regard to fillet hardness (Table 3), which is similar to the findings of Stien et al. [4]. However, there were significant differences between fillet locations, where the anterior part was harder than the middle or the posterior part for all the groups. Hemre et al. [35] showed that the best location to measure texture in cod was towards the tail region just posterior to the anus as supported by less variation between replicates. Similarly, our results showed less variation between replicates for the middle or posterior part of the fillets.

Fillet colour for the different groups at the day of harvest and after 7 days of storage is shown in Table 4. At day 0 , all colour parameters were significantly different between treatments. Fillets of the control group exhibited higher $L^{*}$ (lightness), lower $a^{*}$ (redness) and higher hue values compared to the other groups. In addition, the chroma values for the fillets of the control group were lower than the fillets of anaesthetised $\operatorname{cod}(p<0.05)$. Fillets of cod subjected to pre-slaughter stress had lower $b^{*}$ (yellowness) and hue values, in addition to a higher whiteness values, compared to the other groups. According to the hue values, the fillets of the rested harvested cod (percussion stunned and anaesthetised) were more yellow than the fillets of the stressed cod.

After 7 days of storage, there were less differences between the groups than at the day of harvest. The fillets of the control group had still higher lightness ( $L^{*}$ values) than the other two groups, while the fillets were less red (lower $a^{*}$ values), and the hue values were higher (more yellow) than the fillets of cod subjected to pre-slaughter stress. However, the other measured colour components were not significantly different between groups. Digre et al. [32] did also find significant stress-dependent differences in $a^{*}, b^{*}$, hue and chroma values prior to electrical stunning of cod. Olsen et al. [36] reported higher heme-pigment contents in loins of stressed bled cod, compared to unstressed bled cod. They suggested that this can be explained by redistribution of blood from the intestines to the muscle to prepare for increased muscle activity and escape. In contrast to our results, Stien et al. [4] found significantly higher $L^{*}$-values in stressed cod compared to unstressed cod when filleted pre-rigor. Furthermore, Bosworth et al. [11] found that channel catfish sedated with AQUI-S ${ }^{\mathrm{TM}}$ before exposure to saturated $\mathrm{CO}_{2}$ exhibited lower $L^{*}$ values after 1,4 , and 7 days and lower $a^{*}$ values after 1 day of ice storage compared to stressed fish (industry transported), while $b^{*}$ value was not affected by treatment. When considering the effect of storage time, all fillets became lighter $(p<0.05)$, which is comparable to what Erikson and Misimi [21] found for Atlantic salmon fillets. Furthermore, fillets of cod subjected to AQUI-S ${ }^{\mathrm{TM}}$ became more white (higher whiteness values), while the fillets of percussion stunned cod had a higher chroma value after 7 days of storage $(p<0.05)$. The impact of storage time for fillets of cod subjected to pre-slaughter stress were expressed with higher $b^{*}$, hue angle and chroma values.

It should be noted that the $a^{*}$ values reported in this study were very high compared to what is previously reported for farmed Atlantic cod using the same method for colour assessments, computer vision method, as we did [32]. A possible explanation is that the fillets in this experiment were quite pinkish and some of the fillets were discoloured with brown spots. Figure 1 illustrates the diversity of the colour of the fillets in the experiment. Taken together, pre-slaughter handling stress did in some extent affect fillet colour. Immediately after killing, the fillets of the rested harvested cod (percussion stunned and AQUI-S ${ }^{\mathrm{TM}}$ anaesthetised) were more yellow than the fillets of the stressed cod, whereas after 7 days of ice storage the fillets of the stressed cod were darker and more red than the fillets of the percussion stunned cod.

\section{Descriptive sensory evaluation}

The only sensory differences between the groups were related to the appearance of the fillets (Fig. 2). The AQUI$\mathrm{S}^{\mathrm{TM}}$ group had a slightly more shiny surface ('glossiness' score of 5.3) than the stressed group (score of 5.0; $p<0.01)$. In addition, both fillets of cod subjected to AQUI-S ${ }^{\mathrm{TM}}$ and percussion stunning had slightly higher whiteness scores (6.5) than the fillets of cod exposed to preslaughter stress $(6.2)(p<0.05)$. No differences with regard to odour, flavour or texture were observed. In contrast, Sveinsdóttir et al. [7] found significant differences in fillet texture between unstressed and stressed farmed cod, evaluated by a sensory trained panel. Their unstressed cod were individually harvested and immediately stunned by a blow to the head whereas the stressed fish were exposed to ante-mortem crowding for $30 \mathrm{~min}$.

Hemre et al. [35] studied the effect of season, light regime and diet on the sensory attributes of rested, harvested (anaesthetised with benzocain and killed with a blow to the head), farmed Atlantic cod and found significant differences between the treatments on eight out of 19 attributes related to appearance, odour, aroma and texture. However, in most cases the differences were modest.

The panel was not informed that some of the fish had been exposed to AQUI-S ${ }^{\mathrm{TM}}$, but since they did not find 
Table 3 Fillet hardness $(N)$ measured at three locations (anterior, middle and posterior part of the fillets) of farmed Atlantic cod from different groups: percussion stunned (Control), anaesthetised (AQUI-S ${ }^{\mathrm{TM}}$ ) or stressed by chasing for 30 min (Stress) determined after 7 days of ice storage

\begin{tabular}{llll}
\hline Groups & Control & AQUI-S & Stress \\
\hline Anterior & $20.5 \pm 2.4^{\mathrm{a}}$ & $20.4 \pm 1.6^{\mathrm{a}}$ & $18.3 \pm 1.4^{\mathrm{a}}$ \\
Middle & $13.2 \pm 0.9^{\mathrm{b}}$ & $14.2 \pm 1.2^{\mathrm{b}}$ & $13.4 \pm 1.1^{\mathrm{b}}$ \\
Posterior & $11.6 \pm 1.4^{\mathrm{b}}$ & $10.7 \pm 0.8^{\mathrm{b}}$ & $11.1 \pm 0.8^{\mathrm{b}}$ \\
\hline
\end{tabular}

Different letters (a-b) indicate significant differences between locations $(p<0.05)$. No differences between treatments were observed $(p>0.05)$. Mean $\pm \operatorname{SEM}(n=12-13)$

Table 4 Atlantic cod fillet colour. The fish had been subjected to different pre-slaughter treatments: percussion stunned (Control ${ }^{\mathrm{TM}}$ Stress) determined at the day of slaughter and after 7 days of ice storage

\begin{tabular}{|c|c|c|c|}
\hline & Control & AQUI-S ${ }^{\mathrm{TM}}$ & Stress \\
\hline \multicolumn{4}{|c|}{ Day 0 (pre-rigor) } \\
\hline$L^{*}$ & $69.5 \pm 0.8^{\mathrm{a}}$ & $67.1 \pm 0.4^{\mathrm{b}}$ & $65.5 \pm 0.6^{\mathrm{b}}$ \\
\hline$a^{*}$ & $10.5 \pm 0.6^{\mathrm{a}}$ & $13.1 \pm 0.6^{\mathrm{b}}$ & $14.9 \pm 0.6^{\mathrm{b}}$ \\
\hline$b^{*}$ & $21.3 \pm 0.3^{\mathrm{a}}$ & $21.3 \pm 0.2^{\mathrm{a}}$ & $18.6 \pm 0.4^{\mathrm{b}}$ \\
\hline Hue $\left({ }^{\circ}\right)$ & $63.9 \pm 1.2^{\mathrm{a}}$ & $58.5 \pm 1.2^{\mathrm{b}}$ & $51.4 \pm 1.5^{\mathrm{c}}$ \\
\hline Chroma & $23.8 \pm 0.3^{\mathrm{a}}$ & $25.1 \pm 0.3^{\mathrm{b}}$ & $23.9 \pm 0.2^{\mathrm{a}}$ \\
\hline Whiteness & $5.5 \pm 1.2^{\mathrm{a}}$ & $3.1 \pm 0.5^{\mathrm{a}}$ & $9.9 \pm 0.8^{\mathrm{b}}$ \\
\hline \multicolumn{4}{|c|}{ Day 7 (post-rigor) } \\
\hline$L^{*}$ & $74.7 \pm 0.9^{\mathrm{a}^{*}}$ & $72.3 \pm 0.2^{\mathrm{b}^{*}}$ & $71.5 \pm 0.6^{\mathrm{b}^{*}}$ \\
\hline$a^{*}$ & $12.1 \pm 0.7^{\mathrm{a}}$ & $13.8 \pm 0.4^{\mathrm{ab}}$ & $14.5 \pm 0.6^{\mathrm{b}}$ \\
\hline$b^{* \mathrm{NS}}$ & $21.8 \pm 0.6$ & $21.6 \pm 0.3$ & $20.9 \pm 0.3^{*}$ \\
\hline Hue $\left(^{\circ}\right)$ & $61.0 \pm 1.8^{\mathrm{a}}$ & $57.5 \pm 0.7^{\mathrm{ab}}$ & $55.4 \pm 1.2^{\mathrm{b}^{*}}$ \\
\hline Chroma $^{\text {NS }}$ & $25.1 \pm 0.4^{*}$ & $25.6 \pm 0.3$ & $25.5 \pm 0.3^{*}$ \\
\hline Whiteness $^{\text {NS }}$ & $9.2 \pm 1.6$ & $7.5 \pm 0.9^{*}$ & $8.9 \pm 1.0$ \\
\hline
\end{tabular}

Different letters $(\mathrm{a}-\mathrm{c})$ indicate significant differences between the groups $(p<0.05)$. Significant differences between days 0 and 7 on the fillets from different groups are indicated by an asterisk $(*)$ on the results from day $7(p<0.05)$. NS = no significant differences between groups $(p>0.05)$. Mean \pm SEM $(n=11-13)$

significant differences in taste between treatments, this indicated that AQUI-S ${ }^{\mathrm{TM}}$ did not produce an off-taste. Meinertz et al. [14] studied isoeugenol concentrations in rainbow trout skin-on fillets after exposure to AQUI-S ${ }^{\mathrm{TM}}$ at different temperatures, durations and concentrations. At $12{ }^{\circ} \mathrm{C}$, the concentration of isoeugenol in fillet tissues from fish exposed to $14 \mathrm{mg} \mathrm{L}^{-1}$ AQUI-S ${ }^{\text {TM }}$ for 60 min was significantly greater than isoeugenol concentration in fillet tissue from fish exposed to $34 \mathrm{mg} \mathrm{L}^{-1}$ AQUI-S ${ }^{\mathrm{TM}}$ for 10 min. Consequently, it seems that low doses of AQUI-S ${ }^{\mathrm{TM}}$ and long exposure durations results in higher isoeugenol concentrations in fillets compared to high doses and shorter exposure durations. In our study, a low dose of AQUI-S ${ }^{\mathrm{TM}}$ was used, the exposure times varied and the water temperature were constantly around $12{ }^{\circ} \mathrm{C}$. Our fillets were briefly washed under cold running tap water. The fact that our exposure times were rather long (16-54 $\mathrm{min})$, and the panel did not detect an off-taste, suggests that there are also other factors involved as to whether AQUI-S ${ }^{\mathrm{TM}}$ will produce an off-taste on the final product. Taken together, the results indicate that high doses and low exposure times should be employed. In practise, stunning of smaller batches of fish, and/or quick transfer to the next processing step (including washing) might therefore be suitable measures to take.

\section{Conclusions}

In terms of quality, fillets of cod subjected to AQUI-S ${ }^{\mathrm{TM}}$ anaesthesia had significantly higher IMP contents and lower K-values, indicating a better freshness, than fillets of cod exposed to pre-slaughter stress, after 7 days of ice storage. Furthermore, pre-slaughter handling stress did to some extent affect fillet colour. Immediately after killing the fillets of rested, harvested cod were more yellow than the fillets of stressed cod, whereas after 7 days of ice storage the fillets of stressed cod were darker and redder 


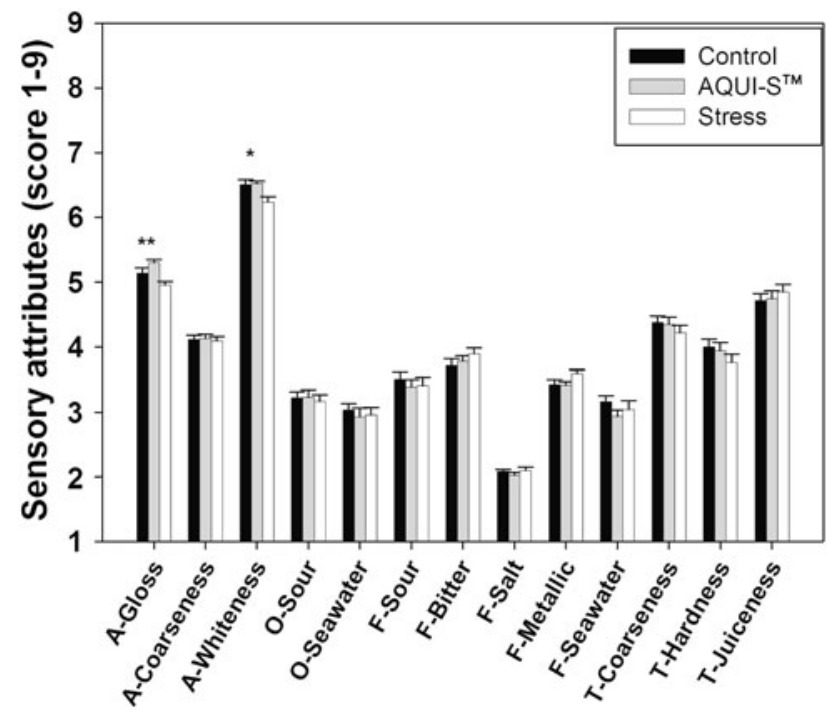

Fig. 2 Sensory evaluation of cooked cod fillets after ice storage for 6-7 days. The effect of pre-slaughter handling stress was studied by subjecting the fish to the following treatments: percussion stunned (Control), anaesthetised (AQUI-S ${ }^{\mathrm{MM}}$ ), or stressed by chasing for $30 \mathrm{~min}$ (Stress). Asterisks indicate significant differences $\left({ }^{*} p<0.05\right.$; $* * p<0.01)$. Mean $\pm \operatorname{SEM}(n=10)$

than the fillets of percussion stunned cod. The benefit of harvesting cod in a rested condition was according to a trained sensory panel, a slightly improvement of the appearance of the fillets (slightly more shiny surface and higher whiteness scores). Our results indicate that AQUI-S ${ }^{\mathrm{TM}}$ might not give any off-taste.

Acknowledgments Live fish handling, slaughter and assessment of stress and fillet quality was carried out in the laboratories at SINTEF Fisheries and Aquaculture. The sensory assessment was carried out at NOFIMA Mat AS, Ås, Norway. This work was part of the project 'Establishing an ethical, standardised slaughter line for white fish (cod)' financed by the Research Council of Norway (project no. $164715 / \mathrm{S} 40)$.

Open Access This article is distributed under the terms of the Creative Commons Attribution Noncommercial License which permits any noncommercial use, distribution, and reproduction in any medium, provided the original author(s) and source are credited.

\section{References}

1. SSB (2010) http://www.ssb.no/fiskeoppdrett/. Accessed 3 Nov 2010

2. European Food Safety Authority (2009) Scientific opinion of the panel on animal health and welfare on a request from the European Commission on species-specific welfare aspects of the main systems of the main systems of stunning and killing of farmed Atlantic salmon. EFSA J 2012:1-77

3. Robb DHF, Kestin SC (2002) Methods used to kill fish: field observations and literature reviewed. Anim Welf 11:269-282
4. Stien LH, Hirmas E, Bjornevik M, Karlsen O, Nortvedt R, Rora AMB, Sunde J, Kiessling A (2005) The effects of stress and storage temperature on the colour and texture of pre-rigor filleted farmed cod (Gadus morhua L.). Aquac Res 36:11971206

5. Kristoffersen S, Tobiassen T, Steinsund V, Olsen RL (2006) Slaughter stress, postmortem muscle $\mathrm{pH}$ and rigor development in farmed Atlantic cod (Gadus morhua L.). Int J Food Sci Technol 41:861-864

6. Misimi E, Erikson U, Digre H, Skavhaug A, Mathiassen JR (2008) Computer vision-based evaluation of pre- and postrigor changes in size and shape of Atlantic cod (Gadus morhua) and Atlantic salmon (Salmo salar) fillets during rigor mortis and ice storage: effects of perimortem handling stress. J Food Sci 73:E57-E68

7. Sveinsdóttir K, Martinsdóttir E, Thórsdóttir F, Schelvis R, Kole A, Thórsdóttir I (2010) Evaluation of farmed cod products by a trained sensory panel and consumers in different test settings. J Sens Stud 25:280-293

8. Sigholt T, Erikson U, Rustad T, Johansen S, Nordtvedt TS, Seland A (1997) Handling stress and storage temperature affect meat quality of farmed-raised Atlantic salmon (Salmo salar). J Food Sci 62:898-905

9. Jerrett AR, Stevens J, Holland AJ (1996) Tensile properties of white muscle in rested and exhausted Chinook salmon (Oncorhynchus tshawytscha). J Food Sci 61:527-532

10. Robb DHF (2001) The relationship between killing methods and quality. In: Kestin SC, Warris PD (eds) Farmed fish quality. Blackwell, Cornwall

11. Bosworth BG, Small BC, Gregory D, Kim J, Black S, Jerrett A (2007) Effects of rested-harvest using the anesthetic AQUI-S on channel catfish, Ictalurus punctatus, physiology and fillet quality. Aquac 262:302-318

12. Erikson U (in press) Assessment of different stunning methods and recovery of farmed Atlantic salmon: Isoeugenol, nitrogen, and three levels of carbon dioxide. Anim Welf

13. Kildea MA, Allan GL, Kearney RE (2004) Accumulation and clearance of the anaesthetics clove oil and AQUI-S ${ }^{\mathrm{TM}}$ from the edible tissue of silver perch (Bidyanus bidyanus). Aquaculture 232:265-277

14. Meinertz JR, Greseth SL, Schreier TM, Bernardy JA, Gingerich WH (2006) Isoeugenol concentrations in rainbow trout (Oncorhynchus mykiss) skin-on fillet tissue after exposure to AQUI-S ${ }^{\mathrm{TM}}$ at different temperatures, durations, and concentrations. Aquaculture 254:347-354

15. Fletcher GC, Corrigan VK, Summers G, Leonard MJ, Jerrett AR, Black SE (2003) Spoilage of rested harvested king salmon (Oncorhynchus tshawytscha). J Food Sci 68:2810-2816

16. Schoettger RA, Julin M (1967) Efficacy of MS-222 as an anesthetic on four salmonids. Investigations in fish control No 13 United States Bureau of Sport Fisheries and Wildlife Resource publication No. 19

17. Erikson U, Beyer AR, Sigholt T (1997) Muscle high-energy phosphates and stress affect K-values during ice storage of Atlantic salmon (Salmo salar). J Food Sci 62:43-47

18. Sellevold OFM, Jynge P, Aarstad K (1986) High performance liquid chromatography: a rapid isocratic method for determination of creatine compounds and adenine nucleotides in myocardial tissue. J Mol Cell Cardiol 18:517-527

19. Eide O, Børresen T, Strøm T (1982) Minced fish production from capelin (Mallotus villosus) a new method for gutting, skinning and removal of fat from small fatty fish species. J Food Sci 47:347-349, 354

20. Andersen UB, Strømsnes AN, Steinsholt K, Thomassen MS (1994) Fillet gaping in farmed Atlantic salmon (Salmo salar). Nor J Agric Sci 8:165-179 
21. Erikson U, Misimi E (2008) Atlantic salmon skin and fillet color changes effected by perimortem handling stress, rigor mortis, and ice storage. J Food Sci 73:C50-C59. doi:10.1111/j17503841200700617

22. Park JW (1994) Functional protein additives in surimi gels. J Food Sci 59:525-527

23. ISO (1993) Sensory analyses-general guidance for the selection, training and monitoring of assessors-part 1: selected assessors. ISO, Geneva

24. ISO (1985) Sensory analyses-methodology—flavour profile methods. ISO, Geneva

25. ISO (1988) Sensory analysis—-general guidance for the design of test rooms. ISO, Geneva

26. Satterthwaite FE (1946) An approximate distribution of estimates of variance components. Biom Bull 2:110-114

27. Huss HH (1995) Quality and quality changes in fresh fish. In: FAO Fisheries Technical Paper No. 348. FAO, Rome

28. de Jong IC, Ekkel ED, van de Burgwal JA, Lambooij E, Korte SM, Ruis MAW, Koolhaas JM, Blokhuis HJ (1998) Effects of strawbedding on physiological responses to stressors and behavior in growing pigs. Physiol Behav 64:303-310

29. Fraser DI, Dingle JR, Hines JA, Nowlan SC, Dyer WJ (1967) Nucleotide degradation monitored by thin-layer chromatography and associated postmortem changes in relaxed cod muscle. J Fish Res Board Can 24:1837-1841

30. Murata M, Sakaguchi M (1989) The effects of phosphatase treatment of yellowtail muscle extracts and subsequent addition of IMP on flavour intensity. Nippon Suisan Gakkaishi 55:1599-1603

31. Greene DH, Bernatt-Byrne EI (1990) Adenosine triphosphate catabolites as flavour compounds and freshness indicators in pacific cod (Gadus macrocephalus) and pollock (Theragra chalcogramma). J Food Sci 55:257-258

32. Digre H, Erikson U, Misimi E, Lambooij B, Van De Vis H (2010) Electrical stunning of farmed Atlantic cod Gadus morhua L.: a comparison of an industrial and experimental method. Aquac Res 41:1190-1202

33. Saito T, Arai K, Matsuyoshi M (1959) A new method for estimating the freshness of fish. Nippon Suisan Gakkaishi 24:749-752

34. Hultmann L, Rustad T (2002) Textural changes during iced storage of salmon (Salmo salar) and cod (Gadus morhua). J Aquatic Food Prod Tech 11:105-123

35. Hemre GI, Karlsen O, Eckhoff K, Tveit K, Mangor-Jensen A, Rosenlund G (2004) Effect of season, light regime and diet on muscle composition and selected quality parameters in farmed Atlantic cod, Gadus morhua L. Aquac Res 35:683-697

36. Olsen SH, Sorensen NK, Larsen R, Elvevoll EO, Nilsen H (2008) Impact of pre-slaughter stress on residual blood in fillet portions of farmed Atlantic cod (Gadus morhua) - measured chemically and by visible and near-infrared spectroscopy. Aquaculture 284:90-97 